Jurnal Mahasiswa BK An-Nur : Berbeda, Bermakna, Mulia

Volume 7 Nomor 2 Tahun 2021

Tersedia Online: https://ojs.uniska-bjm.ac.id/index.php/AN-NUR

p-ISSN. 2460-9722 | e-ISSN. 2622-8297

\title{
PENDIDIKAN KARAKTER ANAK JALANAN DI SEKOLAH KELAS KHUSUS PASAR LIMA BANJARMASIN
}

\author{
Muhammad Adhitya Hidayat Putra, Mutiani, Jumriani \\ Fakultas Keguruan dan Ilmu Pendidikan, Universitas Lambung Mangkurat, Banjarmasin \\ adhitya.hidayat@ulm.ac.id
}

\begin{abstract}
ABSTRAK
Tujuan penelitian ini adalah untuk mengetahui Gambaran Sekolah Kelas Khusus Pasar Lima dan mengetahui pelaksanaan pendidikan karakter bagi anak jalanan. Penelitian ini merupakan penelitian kualitatif dengan mengambil tempat penelitian di Sekolah Kelas Khusus Pasar Lima Kota Banjarmasin. Pengumpulan data dilakukan dengan melakukan observasi, wawancara dan dokumentasi. Hasil penelitian menunjukan bahwa: Berdirinya sekolah ini sangat membantu anak jalanan yang ada di kota Banjarmasin untuk mendapatkan haknya yaitu dapat mengenyam pendidikan sehingga mereka tidak lagi menjadi anak di jalanan karena mereka didik dan dibina di sekolah ini. Pelaksanaan pendidikan karakter yang ada disekolah ini memberikan dampak positif kepada peserta didik walaupun dalam memberikan pendidikan karakter tanpa ada rencana tertulis tentang karakter yang di tanamkan.
\end{abstract}

Kata kunci: Pendidikan Karakter, Anak Jalanan, Sekolah Kelas Khusus Pasar Lima

\begin{abstract}
The purpose of this study was to determine the description of the Pasar Lima Special Class School and to determine the implementation of character education for street children. This research is a qualitative research by taking the research place at the Pasar Lima Special Class School, Banjarmasin City. Data was collected by conducting observations, interviews and documentation. The results of the study show that: The establishment of this school is very helpful for street children in the city of Banjarmasin to get their rights, namely to be able to receive education so that they are no longer children on the streets because they are educated and fostered in this school. The implementation of character education in this school has a positive impact on students even though in providing character education without a written plan about the instilled character.
\end{abstract}

Keywords: Character Education, Street Children, Pasar Lima Special Class School

Dipublikasikan Oleh :

UPT Publikasi dan Pengelolaan Jurnal

Universitas Islam Kalimantan Muhammad Arsyad Al-Banjari Banjarmasin 


\section{PENDAHULUAN}

Sekolah sebagai lembaga pendidikan mempunyai peranan sebagai tempat berinteraksi suatu masyarakat untuk mendapatkan pendidikan. Sudah semestinya setiap orang ingin memperoleh pendidikan setinggi-tingginya, namun ada sebagian masyarakat yang masih tidak mampu mendapatkan pendidikan yang layak, baik itu dari pendidikan dasar maupun pendidikan lanjutan. Selain itu ada pula masyarakat yang pada awalnya dapat mendapatkan pendidikan namun mereka terhenti di tengah jalan karena masalah sosial dan ekonomi yaitu kurangnya pendapatan keluarga menyebabkan orang tua bekerja keras mencukupi kebutuhan sehari-hari sehingga perhatian orangtua terhadap pendidikan cenderung terabaikan.

Pendidikan di daerah perkotaan sudah selayaknya untuk mendapatkan akses yang mudah dan memiliki kualitas dan kuantitas dari segi layanannya kepada masyarakat maupun dari segi manajemen sekolahnya. Namun, sangat disayangkan apabila fenomena yang muncul saat ini bahwa masih saja terdapat kasus anak putus sekolah di daerah perkotaan, salah satunya di Kota Banjarmasin. Faktor penyebabnya adalah "masalah biaya/ekonomi, kemudian faktor ingin membantu orang tua sehingga mengharuskan anak untuk bekerja, faktor perhatian orang tua, minat anak untuk sekolah, kemudian fasilitas dan lingkungan sekolah" (Siswoyo, 2011 : 14).

Fenomena sosial yang muncul dari perkembangan masalah ekonomi yang yang tidak merata di daerah perkotaan, yakni banyaknya timbul anak jalanan. Anak jalanan merupakan anak yang menghabiskan sebagian besar waktunya untuk melakukan berbagai kegiatan hidup sehari-hari di jalanan, baik itu untuk mencari nafkah atau berkeliaran di jalanan atau tempat-tempat umum lainnya. Sehingga perilaku dan pola pikir mereka juga berubah menjadi merosot. Karena mereka hidupnya sehari-hari di jalanan yang tak tau arah dan tujuan (Departemen Sosial, 2005: 5).

Dalam hal itu, mengakibatkan banyak anak yang menjadi anak jalanan, karena faktor masalah biaya/ekonomi. Sehingga perilaku dan pola pikir mereka juga berubah menjadi merosot. Karena mereka hidupnya sehari-hari di jalanan yang tak tau arah tujuan. Oleh karena itu, untuk mengatasi kemerosotan moral serta perilaku anak jalanan tersebut dengan cara membenahi karakter anak jalanan. Mereka juga butuh sebuah pendidikan seperti halnya anak yang mampu untuk sekolah. selain itu, mendapatkan sebuah pendidikan anak jalanan juga membutuhkan pendidikan karakter untuk mengubah dan memperbaiki perilaku dan pola pikir mereka agar menjadi anak yang berakhlak baik.

Menanamkan karakter anak bisa dilakukan baik melalui pendidikan formal maupun nonformal. Salah satu lembaga yang berperan dan menampung anak jalanan dalam pedidikan serta menanamkan karakter anak adalah Sekolah Kelas Khusus Pasar Lima Kota Banjarmasin yang menangani berbagai anak jalanan. Penanaman karakter bisa dilakukan pada siapa saja tidak terkecuali bagi anak jalanan.

Anak jalanan selain membutuhkan pendidikan juga membutuhkan pendidikan karakter. Selama ini anak jalanan kurang mendapatkan perhatian dari orang tuanya terlebih anak jalanan yang terjun ke jalanan dengan berbagai alasan diantaranya karena disuruh orang tuanya untuk bekerja mengumpulkan uang. Anak jalanan yang melakukan aktivitas di jalanan sudah merasakan bagaimana rasanya mendapatkan uang, tidak jarang dari anak jalanan yang tergiur untuk ikut ke jalananan demi untuk mendapatkan uang. Ada juga alasan mereka terjun ke jalanan karena disuruh orang tua, dengan orang tua mereka mengharapkan anaknya untuk mengamen, secara tidak langsung membentuk karakter anak tersebut sesuai dengan kehidupannya yaitu ada yang di jalanan.

Sebagai salah satu usaha untuk mengembalikan anak jalanan agar tidak banyak membuang waktu ke jalanan adalah dengan adanya sebuah lembaga pendidikan yaitu Sekolah Kelas Khusus Pasar Lima Kota Banjarmasin yang membantu mereka mengurangi aktivitas di jalanan. Sekolah ini sebagai sebuah lembaga untuk membantu penanganan anak jalanan dan merupakan sebagai pusat kegiatan pendidikan bagi anak jalanan yang bertujuan untuk memberikan sebuah pendidikan seperti pembelajaran dan pendidikan karakter. Sekolah Kelas Khusus Pasar Lima merupakan Sekolah yang berdedikasi khusus untuk para anak-anak jalanan, terletak di dalam sebuah komplek Pasar Lima Banjarmasin. Ruang Kelas pada sekolah tersebut menggunakan pasar yang tidak dipakai. Sekolah Kelas Khusus Pasar Lima sangat membantu anak jalanan dan anak-anak yang ada di sekitar kawasan Pasar Lima tersebut, karena tidak memungut biaya sedikitpun atau gratis terhadap orang tua. Tujuan semula dari sekolah ini didirikan adalah hanya untuk memberikan kehidupan yang layak bagi mereka yang kurang beruntung agar bisa mendapatkan pendidikan seperti halnya orang yang mampu untuk besekolah, agar mereka tidak menjadi anak gelandangan. Selain mendapatkan pendidikan, mereka juga dibina dan dibimbing untuk

Dipublikasikan Oleh :

UPT Publikasi dan Pengelolaan Jurnal

Universitas Islam Kalimantan Muhammad Arsyad Al-Banjari Banjarmasin 
merubah anak jalanan memiliki masa depan yang lebih baik seperti anak yang memiliki keluarga utuh bukan anak jalanan. Sekolah ini mendidik anak jalanan dengan sebaik mungkin tentunya dengan pendidikan karakter. Hal ini untuk membentuk perilaku mereka agar lebih baik lagi dan berakhlak karimah untuk masa depannya.

Suasana kekeluargaan dan kedekatan yang dibangun oleh pihak sekolah untuk menambah hubungan yang harmonis dalam pembibingan merupakan salah satu cara untuk menjadikan dan mengembalikan anak-anak jalanan untuk tidak terjun ke jalanan lagi untuk meminta-minta dan mengemis. Dengan hubungan kekeluargaan merupakan salah satu cara sedikit demi sedikit untuk menjadikan mereka tidak terjun lagi ke jalanan yang tanpa tujuan tertentu. Sekolah ini cukup baik untuk diteliti dalam upaya pelaksanaan penanamanan nilai-nilai pendidikan karakter bagi anak jalanan. Mendidik anak jalanan tidak semudah mendidik anak biasa yang tidak mengenal jalanan. Pihak sekolah dalam hal ini guru di Sekolah Kelas Khusus Pasar Lima berusaha untuk menanamkan karakter positif pada anak-anak jalanan tersebut. Guru berusaha untuk mengembalikan anak jalanan tersebut agar tidak lagi terjun ke jalanan dengan memberikan pendidikan kepada mereka salah satunya dengan belajar bersama di sekolah ini serta memberikan motivasi-motivasi kehidupan dalam menjalani kehidupan sehari-hari.

Melalui pembinaan tersebut menunjukkan sedikit demi sedikit perubahan pada anak jalanan. Melihat pada perubahan tersebut upaya yang dilakukan pihak sekolah dalam menamakan pendidikan karakter dalam berbagai kegiatan merupakan hal yang menarik untuk ditiliti. Dari sinilah penulis tertarik untuk melakukan penelitian anak jalanan yang ada di Sekolah Khusus Pasar Lima Kota Banjarmasin. Maka dari itu penulis melakukan penelitian dengan judul Pendidikan Karakter Bagi Anak Jalanan di Sekolah Kelas Khusus Pasar Lima Banjarmasin.

\section{METODE}

Penelitian ini menggunakan pendekatan kualitatif, karena data yang diperoleh sebagian besar didapat dari observasi di lapangan, wawancara, dan dokumentasi. Penelitian kualitatif adalah penelitian yang bertujuan untuk mendapatkan pemahaman yang mendalam tentang masalah-masalah manusia dan sosial. Bukan mendeskripsikan bagian permukaan dari suatu realitas sebagaimana dilakukan penelitian kuantitatif dengan positivismenya. Peneliti mengeinterpretasikan bagaimana subjek memperoleh makna dari lingkungan sekeliling, dan bagaimana makna tersebut memangaruhi perilaku mereka (Gunawan, 2013: 85).

Metode yang digunakan adalah metode deskriptif. Metode deskriptif adalah penelitian yang menggambarkan suata keadaan yang apa adanaya di lapangan. Penggambaran ini dapat berupa perorangan, kegiatan, peristiwa atau sekelompok individu yang terkait oleh tempat, waktu/ikatan tertentu. Studi ini yang diarahkan untuk menghimpun data, dan memperoleh pemahaman (Ghony dan Fauzan, 2012: 85).

Tempat penelitian ini adalah di Sekolah Kelas Khusus Pasar Lima Kota Banjarmasin, subyek penelitian adalah anak-anak jalanan (peserta didik), guru dan kepala sekolah serta masyarakat. Metode pengumpulan data berupa obeservasi, wawancara dan dokumentasi. Metode analisis data menggunakan metode analisis data berupa reduksi data, display data, dan verifikasi/kesimpulan.

\section{HASIL DAN PEMBAHASAN \\ Deskripsi Sekolah Kelas Khusus Pasar Lima Untuk Anak Jalanan di Kota Banjarmasin.}

Sekolah Kelas Khusus Pasar Lima ini berdiri pada tanggal 18 Agustus 1988. Sekolah ini bertujuan untuk menampung anak-anak jalanan di kota Banjarmasin dan yang sering berkeliaran di sekitar area pasar. Mereka pada umumnya berasal dari keluarga kurang mampu yang tidak bisa bersekolah di sekolah umum. Berdasarakn hasil wawancara dengan Yunus, sejarah berdirinya sekolah ini tidak lepas dari para pejabat di Banjarmasin gagasan dan inisiatif dari beberapa tokoh masyarakat yang juga sebagian pejabat dari Dinas Pendidikan, Dinas Sosial, dan guru sekolah dan beberapa tokoh lainnya yang ada di Banjarmasin di tahun 1988. Tujuan sekolah ini didirikan adalah untuk memberikan kehidupan yang layak bagi anak jalanan yang kurang beruntung agar bisa mengenyam pendidikan seperti halnya orang mampu dari segi ekonomi, agar mereka tidak menjadi seorang gelandangan.

Berdasarkan temuan penelitian, Sekolah Kelas Khusus Pasar Lima ini berbeda pada sekolah umumnya. Sebab sekolah ini memakai bangunan Pasar Lima yang tidak terpakai lagi, Pasar Lima adalah sebuah pasar yang terletak di wilayah Banjarmasin tepatnya di Kecamatan Banjarmasin Tengah. Sebagaimana yang diungkapkan Zaini, melihat banyaknya anak yang berada di jalanan atau berkeliaran di pasar dan tempat-tempat umum lainnya

Dipublikasikan Oleh : 
baik itu untuk bekerja dan meminta-minta di jalanan yang tidak mampu untuk sekolah. Maka, di tempat tersebut dibangunlah sebuah sekolah khusus yang diperuntukan untuk anak-anak jalanan, gelandangan, atau yang tidak mampu bersekolah yang dibangun oleh Dinas Pendidikan pada tanggal 18 Agustus 1988

Sekolah ini yang pada awalnya hanya dilaksanakan sebuah program SD Kelas Khusus Pasar Lima, untuk meningkatkan jenjang pendidikan anak maka dibuka pendidikan setara SMP pada tahun 2012 untuk anak-anak jalanan yang putus sekolah. Sejak berdirinya sekolah ini, sarana dan prasarana sekolah ini sangat minim dengan peralatan yang seadanya. Tetapi, lama-kelamaan sekolah ini banyak diketahui orang, sehingga banyak dari donator dan relawan-relawan yang ikut membantu sekolah ini.

Berdasarkan temuan penelitian, Sekolah Kelas Khusus Pasar Lima ini pada awalnya memiliki dua ruang kelas dan pada tahun 2018 bertambah satu ruangan yang digunakan untuk kegiatan keterampilan peserta didik. Sebagaimana diungkapkan oleh Nursinah, untuk ruangan keterampilan itu, nantinya diajarakan sebuah keterampilan seperti maulid habsy, memasak dan menjahit. Ruangan itu dibangun guna untuk meningkatkan bakat dan keterampilan peserta didik nantinya, serta sebagai bekal dalam dunia kerja ketika mereka sudah lulus nantinya.

Berkenaan dengan pembelajaran sendiri, Sekolah Kelas Khusus ini dilaksanakan setiap hari, mulai hari senin-sabtu. Tetapi, untuk jam masuknya berbeda dengan sekolah pada umumnya. Jam masuk sekolah ini pukul 09.00-11.00 siang. Hal tersebut menyesuaikan dengan keadaan peserta didik, karena dari mereka ada yang bekerja, sehingga sekolah ini menyesuaikan dengan keadaan peserta didik. Selanjutnya, untuk mata pelajaran sendiri sama dengan mata pelajaran sekolah pada umunya. Sekolah ini tidak dikenakan biaya atau gratis, peserta didik di sekolah ini juga mendapakan uang yaitu 5.000, uang tersebut diberikan per tiga bulan. Sebagaimana yang dikatakan Yunus, untuk uang tersebut diberi untuk memberi motivasi mereka agar mereka rajin ke sekolah dan tidak melakukan aktivitas di jalanan untuk meminta-minta atau mengemis.

\section{Pendidikan Karakater Bagi Anak Jalanan di Sekolah Kelas Khusus Pasar Lima Kota Banjarmasin.}

Apabila kita menginginkan karakter anak-anak di sekeliling kita baik maka baiknya terlebih dahulu kita mencontohkan dan memberikan pemahaman tentang baik dan buruk, karena persoalan karakter menyangkut baik dan buruk. Karakter bukan sebuah persoalan yang dapat dibentuk secara mudah dan cepat, namun untuk menanamkan karakter memerlukan waktu lama dan membutuhkan sebuah proses yang berkelanjutan (Wawancara dengan Bapak Yunus). Proses dalam menanamkan nilai-nilai karakter tersebut yang diperlukan sehingga dapat menjadi sebuah bentuk ajaran dalam diri anak sebuah karakter yang ingin dibentuk. Adanya sebuah proses pembentukan itulah yang menjadikan seorang anak dapat bertahan dalam karakter yang sudah dibentuk. Karakter anak jalanan bisa terbentuk dari orang tuanya dan kemudian selanjutnya lingkungan sekitar anak jalanan yang membentuk mereka. Anak-anak akan mencontoh perilaku yang dilakukan orang tuanya.

Berdasarkan pengamatan langsung di lapangan, penulis adanya menemukan pelaksanaan pendidikan karkater bagi anak jalanan di Sekolah Kelas Khusus Pasar Lima Banjarmasin. Pendidikan karakter yang diberikan dan diajarkan di sekolah ini merupakan pendidikan karakter yang bisa memberikan motivasimotivasi kehidupan terhadap anak jalanan tersebut untuk bisa menjalani hidup tanpa harus bekerja sebagai pengamen atau pengemis dan hidup di jalanan tanpa arah dan tujuan yang jelas. Banyak waktu mereka gunakan di jalan untuk mengamen dan mengemis, maka perilaku dan watak maupun pola pikir mereka yang terbentuk adalah watak dan perilaku jalanan dimana kehidupan berlaku dengan keras dan tidak teratur. Oleh karena itu, pihak sekolah dalam hal ini guru menyebutkan bahwa pendidikan karakter di sekolah ini adalah sebuah penanaman nilai-nilai kehidupan, karena pengemis khususnya anak-anak yang menjadi jalanan tidak seperti kehidupan pada anak dari seorang yang mampu, dimana untuk makan sehari dan bayar biayai sekolah saja anak jalanan harus bekerja terlebih dahulu sebagai mengamen dan meminta-minta agar bisa bersekolah. Nilai-nilai kehidupan terletak pada susahnya mencari uang agar mereka mengerti dan tidak sembarangan untuk mengambil barang ataupun miliki orang lain tanpa seizin pemiliknya. Maka pihak sekolah selalu berusaha menanamkan nilai-nilai kehidupan yang sesuai dengan pola pikir mereka.

Memberikan pendidikan karakter pihak sekolah dalam hal ini guru memberikan beberapa contoh tentang perilaku berkarakter itu sendiri seperti sopan santun, berkata jujur, jangan meminta-meminta dan tangan diatas lebih baik pada tangan dibawah. Pada dasaranya pendidikan karakter dilaksanakan dan diajarkan kepada anak jalanan dimanapun dan

Dipublikasikan Oleh : 
kapanpun. Mengingat dari pemahaman tersebut yaitu membentuk sebuah sifat maupun prilaku baik maupun buruk. Membentuk hal tersebut bisa dimanapun dan kapanpun. Mereka selalu dinasehati dan dibimbing agar menjadi anak yang berkahlak baik serta mereka juga diberikan pendidikan agama sehingga mereka bisa membedakan mana yang baik dan mana yang buruk (wawancara dengan Zaini).

Pendidikan sangat penting bagi anak jalanan untuk membentuk sikap dan perilau mereka agar menjadi anak yang berakhlak baik serta untuk mengubah pola pikir mereka sehingga tidak lagi atau berkurang untuk ke jalanan dengan tujuan mengamen atau meminta-minta. Dilihat dari hasil ini di harapkan mereka mampu menerapkannya dalam kehidupan sehari-hari mereka dan sebagai bekal untuk masa depan mereka agar mereka tidak dipandang lagi menjadi anak yang buruk di mata masyrakat.

Sekolah ini memberikan bimbingan, binanaan dan mendidik anak jalanan dengan memberikan nasehat, motivasi dan dorongan untuk berprilaku sesuai norma sosial dan norma agama. Dengan kata lain pendidikan karakter sangat pentiing dan memiliki peran untuk menjadikan anak jalanan memiliki karakter yang baik yang diaplikasikan dalam kehidupan sehari-hari mereka. Dengan demikian, pentinganya pendidikan karakter bagi mereka selain bekal pengetahuan juga mendapatkan sebuah pembentukan perilaku yang berkarakter.

\section{PENUTUP}

Sekolah Kelas Khusus merupakan sekolah yang berdedikasi untuk menampung dan memberikan pendidikan bagi anak jalanan yang ada di kota Banjarmasin. Sekolah Kelas Khusus Pasar Lima memliki peranan penting dalam mengatasi dan membantu permasalahan sosial anak jalanan di Kota Banjarmasin. Adanya sekolah ini memberikan dampak positif dalam memberikan pendidikan bagi anak jalanan. Anak Jalanan di Sekolah ini anak jalanan diberikan pendidikan umum, agama dan pendidikan keterampilan. Selain itu, anak jalanan juga dibina dan dibimbing agara mereka tidak lagi melakukan aktivitas mengesmis maupun meminta-minta. Diharapakan sekolah ini memberikan kontribusi bagi pemerintah kota Banjarmasin dalam mengatasi masalah anak jalanan.

Pendidikan karakter bagi anak jalanan di Sekolah Khusus Pasar Lima ini memberikan pengaruh penting bagi anak jalanan. Dengan adanya penanaman karakter diharapkan anak jalanan menjadi anak yang berahklak mulia nantinya dan dapat diaplikasikan dalam kehidupan sehari-hari mereka.

\section{REFERENSI}

Abbas, E. W. (2014). Pendidikan Karakter.

Departemen Sosial RI. 2001. Intervensi Psikososial. Jakarta: Departemen Sosial RI.

Departemen Sosial RI. 2005. Petunjuk Teknis Pelayanan Sosial Anak Jalanan. Jakarta: Departemen Sosial RI.

Ghony, M. Djunaidi dan Fauzan Almanshur. 2012. Metode Penelitian Kualitatif. Yogjakarta: ArRuzz Media

Gunawan, Imam. 2013. Metode Penelitian Kualitatif: Teori dan Praktik. Jakarta: PT Bumi Aksara.

Hariyanto dan Muchlas Samani. 2013. Pendidikan Karakter: Konsep dan Model. Bandung: PT Remaja Rosdakarya Offset.

Kemendiknas. 2010. Pendidikan Karakter Terintegrasi dalam Pembelajaran di Sekolah Menengah Pertama. Jakarta: Kemendiknas.

Kurniawan, Syamsul. 2013. Pendidikan Karakter: Konsepsi dan Implementasinya secara Terpadu di Lingkungan Keluarga, Sekolah, Perguruan Tinggi, dan Masyarakat. Yogyakarta: Ar-Ruzz Media.

Mulyasa, E. 2014. Manajemen Pendidikan Karakter. Jakarta: PT Bumi Aksara.

Narwanti, Sri. 2011. Pendidikan Karakter Pengintegrasian 18 Nilai Dalam Mata Pelajaran. Yogyakarta: Familia.

Puskur. 2010. Pengembangan Pendidikan Budaya dan Karakter Bangsa. Jakarta: Puskur Balitbang Kementerian Pendidikan Nasional.

Putra, M. A. H. (2019). Building Character Education Through The Civilization Nations Children. The Kalimantan Social Studies Journal, 1(1), 12-17.

Rahman, A. M., Mutiani, M., \& Putra, M. A. H. (2019). Pengaruh kompetensi pedagogik dosen terhadap motivasi belajar mahasiswa pendidikan IPS. Jurnal Darussalam: Jurnal Pendidikan, Komunikasi dan Pemikiran Hukum Islam, 10(2), 375-387.

Siswoyo, Dwi. 2011. Ilmu Pendidikan. Yogyakarta: UNY Press.

Dipublikasikan Oleh :

UPT Publikasi dan Pengelolaan Jurnal

Universitas Islam Kalimantan Muhammad Arsyad Al-Banjari Banjarmasin 